\title{
GAMBARAN PENERIMAAN ORANG TUA DENGAN ANAK RETARDASI MENTAL DI SEKOLAH LUAR BIASA (SLB) C “DG" DAN SLB C “SJ"
}

\author{
Hadi Kosasih \\ Stefani Virlia
}

\begin{abstract}
Mental retardation is disability of intelectual functioning and maladaptive behaviour during development. There are some parents can accept their children but there's also parents that can't accept the reality to have children with mental retardation. The purpose of this research is knowing parental acceptance who have child with mental retardation. The research use quantitative method, use a questionaire to collect data. The subject of this study is the parents who have mental retardation children in SLB DG and SLB SJ as many as 62 parents. Validty test results with product moment correlation was obtained 34 valid items with validity coefficients range from 0.252 up to 0.817 . reliability test results obtained by the cronbach alpha reliability coefficient 0.950 .

The result is parents have low parental acceptance (48\%) towards the mental retardation condition of their children. Factors that influence the parental acceptance are a lack understanding about mental retardation, unpreparedness to face the child's condition, less communication in family, and negative perception about the child limitation.
\end{abstract}

Keywords : parental acceptance, mentally retarded child

\section{A. LATAR BELAKANG}

Keluarga adalah bagian penting dalam kehidupan setiap manusia. Keluarga inti dapat dikatakan lengkap bila terdapat ayah, ibu, dan anak. Anak merupakan karunia yang diberikan pada setiap insan pasangan manusia, yang nantinya akan disebut dengan orang tua. Setiap orang tua umumnya mengharapkan anaknya lahir dengan kondisi yang sehat dan berkembang dengan baik. Hanya saja, tidak semua harapan orang tua tersebut berjalan dengan semestinya. Ada beberapa anak yang harus terlahir dalam kondisi kurang sempurna, cacat, atau berkebutuhan khusus.

Sensus Nasional Biro Pusat Statistik tahun 2006, dari 222.192.572 penduduk Indonesia, sebanyak 0,7\% atau 2.810.212 jiwa adalah penyandang cacat, 601.947 anak $(21,42 \%)$ di antaranya adalah anak cacat usia sekolah (5-18 tahun) termasuk retardasi mental. Sementara itu, menurut data Sekolah Luar Biasa tahun 2006/2007, jumlah peserta didik penyandang cacat yang mengeyam pendidikan baru mencapai $27,35 \%$ atau 87.801 
anak. Berdasarkan jumlah tersebut, populasi anak retardasi mental menempati angka paling besar yaitu 66.610 anak dibanding jumlah anak dengan kecacatan lainnya (Sholihah, Asiyah, dan Matsihoh, 2014). Bila dilihat dari kelompok usia sekolah, jumlah penduduk retardasi mental adalah 62,011 orang, yang terbagi menjadi $60 \%$ berjenis kelamin laki-laki dan $40 \%$ berjenis kelamin perempuan (Jevuska dalam Siswanto dan Farraswati, 2014). Propinsi dengan populasi terbesar anak retardasi mental di Indonesia adalah di DKI Jakarta dan diikuti Jawa Tengah (Sholihah, Asiyah, dan Matsihoh, 2014).

Anak retardasi mental berbeda dengan anak-anak normal pada umumnya. Bila dilihat dari aspek perkembangan fisik, anak dengan retardasi mental umumnya cenderung lebih mudah memiliki atau terkena penyakit dibanding anak-anak normal (Payne dan Patton, 1981). Bila dilihat dari perkembangan kognitif, anak dengan retardasi mental tidak memiliki keterampilan kognitif yang unggul, tidak memilih strategi pemecahan masalah yang memadai (masih bersifat trial and error), dan memiliki kekurangan dalam memori jangka pendek (dalam Permana, Ekowati, \& Nani 2013). Anak retardasi mental juga memiliki kecenderungan untuk menyakiti diri mereka sendiri, seperti memukul kepala sendiri, terus menerus terjatuh, menggigit dan mencakar diri sendiri. (Taylor, Richard, dan Brady, 2005).

Kekurangan yang dimiliki anak retardasi mental tersebut membuat mereka tidak dapat bersekolah di sekolah normal. Suran \& Rizzo (dalam Magunsong 2009) mengatakan anak memerlukan penanganan dari yang terlatih dari tenaga professional jika mereka berbeda secara fisik, psikologis, maupun sosial. Anak retardasi mental memerlukan persyaratan pendidikan yang berbeda dari rata-rata anak normal, dan untuk dapat belajar secara efektif memerlukan program, pelayanan, fasilitas, dan materi khusus (Gearheart dalam Magunsong, 2009). Sekolah luar biasa adalah tempat dan instruksi yang didesain khusus untuk memenuhi kebutuhan-kebutuhan yang tidak lazim dari siswa (Hallahan \& Kauffman dalam Magunsong, 2009). Tujuan penting dari sekolah luar biasa adalah menemukan dan menitikberatkan kemampuan siswa berkebutuhan khusus (Hallahan \& Kauffman dalam Magunsong, 2009).

Peranan sekolah luar biasa terhadap perkembangan anak retardasi mental memang cukup besar. Namun sebenarnya anak akan lebih banyak menghabiskan waktunya bersama dengan orangtuanya. Oleh karena itu, keterlibatan orang tua merupakan hal yang esensial 
Vol. 9 No. 1 April 2016

PSIBERNETIKA

untuk mengembangkan anaknya (Magunsong, 2009). Maulani (2010 dalam Utami, Hasyim, dan Nurmalisa, 2013) juga menambahkan peran orang tua adalah bertanggung jawab menjadi sosok panutan bagi anak dan mengajarkan anak untuk siap masuk dalam kehidupan bermasyarakat demi tercapainya masa depan mereka. Masa anak adalah masa yang kritis dimana pengalaman-pengalaman dasar yang terbentuk pada masa itu akan sulit untuk diubah dan akan terbawa sampai dewasa sehingga perlu dihindari terbentuknya pengalaman-pengalaman negatif pada anak. Begitu pula dengan anak retardasi mental, mereka juga membawa pengalaman-pengalaman yang dialaminya hingga masa dewasa nanti. Oleh karena itu, pengalaman negatif antara anak retardasi mental dengan orang tuanya akan mendatangkan kerugian bagi perkembangan sosial anak tersebut di masa depannya (dalam Permana, Ekowati, Nani 2013).

Peran orang tua diatas dapat diwujudkan dengan baik bila adanya penerimaan orang tua terhadap kondisi anak retardasi mental. Penerimaan orang tua menjadi penting karena dapat memberikan energi dan kepercayaan diri anak untuk lebih berusaha meningkatkan setiap kemampuan yang dimiliki. Orang tua perlu menerima kondisi anak dengan segala kekuranganya karena hal tersebut akan mempengaruhi proses perkembangan pada anak termasuk di dalamnya adalah proses belajar anak (Slameto, 2013). Perkembangan sosial anak retardasi mental akan sangat bergantung pada bagaimana perlakuan dan penerimaan lingkungan khususnya penerimaan orang tua terhadap anak (Permana, Ekowati, Nani 2013).

Pada kenyataannya, tidak semua orang tua dapat menerima kondisi anak dengan retardasi mental. Hal ini terlihat dari hasil wawancara peneliti dengan 5 ibu yang memiiki anak retardasi mental dari sekolah luar biasa (SLB) C DG di daerah Jakarta Pusat, 3 orang tua diantaranya belum dapat menerima keadaan anaknya karena sulitnya mengasuh anak dengan retardasi mental, dan merasa bingung ketika menghadapi tanggapan orang lain yang negatif mengenai anaknya. Dua orang tua lainnya memiliki reaksi yang berbeda di mana mereka selalu berusaha untuk mengembangkan potensi anaknya walau anaknya sangat lambat dalam perkembangan kognitifnya (Komunikasi Personal, 22 Mei-9 Juni 2015). Berdasarkan fenomena dan wawancara diatas, peneliti ingin melakukan penelitian mengenai gambaran penerimaan orang tua di Sekolah Luar Biasa C (SLB C) DG dan SLB C SJ di Jakarta. 


\section{B. TUJUAN PENELITIAN}

Tujuan penelitian ini adalah untuk mengetahui penerimaan orang tua dengan anak retardasi mental di SLB C DG dan SLB C SJ.

\section{TINJAUAN TEORI}

\section{Definisi Penerimaan Orang Tua}

Penerimaan orang tua adalah suatu kondisi dimana orang tua dapat menerima suatu kenyataan, dimana orang tua dapat memberikan kasih, afeksi, perhatian, kenyamanan, dan dukungan kepada anak mereka terlepas keterbatasan anak (Rohner, dan Khalaque, 2002). Menurut Porter (dalam Elianto, dan Hendraeni, 2013) penerimaan orang tua adalah perasaan atau perilaku orang tua yang dapat menerima keberadaan anaknya tanpa syarat, penerimaan merupakan tujuan akhir dari orang tua saat mengetahui anaknya mempunyai kecacatan.

\section{Ciri-Ciri Penerimaan Orangtua}

Porter (dalam Moningsih, 2012) menyebutkan ciri-ciri orang tua yang telah menerima kondisi anaknya, yaitu :

a. Menunjukan sikap menerima dan memberikan perasaan positif

b. Komunikasi tetap terjaga

c. Mendengarkan sesuatu dengan pemikiran terbuka terhadap permasalahan

d. Tidak memaksa untuk mengubah apa yang telah menjadi dasar (potensi) dari bawaan seseorang.

e. Menerima segala keterbatasan yang ada

f. Memberikan dukungan dan cinta setiap waktu, berbagi dalam suka dan duka, tetap mendukung meskipun gagal

g. Mencintai tanpa syarat, tidak meminta cinta yang sama seperti yang ia telah berikanMembuat orang lain mengetahui bahwa dirinya mencintai dan memberikan kasih sayang kepada orang tersebut

h. Senang bersama orang tersebut dan menikmati apa yang mereka lakukan bersama

\section{Faktor-faktor Penerimaan Orang Tua}

Sarasvati (2004) mengatakan banyak hal yang mempengaruhi kesiapan orang tua dalam menghadapi anak dengan retardasi mental, adalah : 
Vol. 9 No. 1 April 2016

PSIBERNETIKA
a. Dukungan dari keluarga besar
b. Kemampuan keuangan keluarga
c. Latar belakang agama yang kuat
d. Sikap para ahli yang mendiagnosa anak
e. Tingkat pendidikan
f. Status perkawinan yang harmonis
g. Sikap masyarakat umum
h. Usia yang matang pada pasangan suami-istri
i. Sarana penunjang seperti pusat terapi, sekolah khusus, dokter ahli dan pusat konseling keluarga.

\section{METODE PENELITIAN}

Penelitian ini menggunakan metode penelitian kuantitatif, dan termasuk ke dalam jenis penelitian deskriptif. Populasi dalam penelitian ini adalah orang tua yang memiliki anak retardasi mental di Jakarta. Peneliti memilih dua Sekolah Luar Biasa (SLB) C, yaitu SLB "DG" yang terletak di Jakarta Pusat dan SLB "SJ" yang terletak di Jakarta Utara sebagai sampel dalam penelitian ini. Teknik sampling yang digunakan adalah purposive sampling, karena sampel dipilih berdasarkan tujuan penelitian.

Instrumen yang digunakan dalam penelitian ini disusun oleh peneliti sendiri berdasarkan teori ciri-ciri penerimaan orang tua dari Porter (dalam Moningsih, 2012). Instrumen ini terdiri dari 39 aitem yang terdiri dari 21 butir aitem favorable dan 18 butir aitem unfavorable. Instrumen ini menggunakan skala likert yang terdiri dari 4 respon yang berbeda yaitu, sangat tidak setuju (STS), tidak setuju (TS), setuju (S), dan sangat setuju (SS).

Jumlah responden dalam penelitian ini adalah 92 orang tua yang memiliki anak retardasi mental di SLB C DG dan SLB C SJ di Jakarta, yang terbagi menjadi 30 orang tua untuk uji coba instrumen dan 62 orang sisanya digunakan untuk mendapatkan gambaran kategori penerimaan. Berdasarkan uji coba instrumen penelitian, didapatkan hasil uji validitas dengan korelasi product moment diperoleh 36 aitem yang valid dengan kisaran koefisien validitas dari 0.252 sampai 0.817 . Hasil uji reliabilitas dengan teknik alpha Cronbach diperoleh koefisien reliabilitasnya 0.950 . 


\section{Reliability Statistics}

\begin{tabular}{ll}
\hline $\begin{array}{l}\text { Cronbach's } \\
\text { Alpha }\end{array}$ & N of Items \\
\hline .950 & 36 \\
\hline
\end{tabular}

\section{E. HASIL}

\section{PENELITIAN}

\section{Gambaran Umum Responden Penelitian}

Adapun gambaran umum responden penelitian ini meliputi usia, jender, pekerjaan, dan tingkat pendidikan terakhir.

Tabel 1. Gambaran Umum Usia

\begin{tabular}{llcc}
\hline No & Usia & Jumlah & persentase \\
\hline 1 & $26-35$ & 6 & 10 \\
2 & $36-45$ & 23 & 37 \\
3 & $46-55$ & 27 & 43 \\
4 & $56-65$ & 2 & 4 \\
5 & Tidak mengisi & 4 & 6 \\
\hline & Total & 62 & 100 \\
\hline
\end{tabular}

Tabel 2. Gambaran Umum Jender

\begin{tabular}{llcc}
\hline No & Jender & Jumlah & Persentase \\
\hline 1 & Pria & 9 & 15 \\
2 & Wanita & 53 & 85 \\
\hline & Total & 62 & 100 \\
\hline
\end{tabular}

Tabel 3. Gambaran Umum Pekerjaan

\begin{tabular}{llcc}
\hline No & Pekerjaan & Jumlah & Persentase \\
\hline 1 & Pegawai Negeri & 3 & 5 \\
2 & Swasta & 11 & 18 \\
3 & Wiraswasta & 13 & 20 \\
4 & Lainnya & 35 & 57 \\
\hline & Total & 62 & 100 \\
\hline
\end{tabular}

Tabel 4. Gambaran Umum Tingkat Pendidikan

\begin{tabular}{lccc}
\hline No & Pekerjaan & Jumlah & Persentase \\
\hline 1 & SD & 3 & 5 \\
2 & SMP & 7 & 11 \\
3 & SMA & 34 & 55 \\
4 & D3 & 8 & 13 \\
5 & S1 & 8 & 13 \\
6 & Tidak Mengisi & 2 & 3 \\
\hline \multicolumn{2}{r}{ Total } & 62 & 100 \\
\hline
\end{tabular}


Vol. 9 No. 1 April 2016

PSIBERNETIKA

Berdasarkan tabel-tabel di atas, terlihat bahwa mayoritas responden penelitian ini adalah wanita (ibu) sebesar 85 persen. Hal ini juga didukung dengan hasil observasi peneliti di dua sekolah tersebut bahwa orang tua yang lebih banyak mengantar anaknya ke sekolah adalah ibu. Selain itu, sebagian besar responden juga berada pada rentang usia 46 sampai 55 tahun (43\%) dan merupakan tamatan pendidikan SMA (55\%).

\section{Gambaran Kategori Penerimaan Orang Tua}

Tabel 5. Kategori Skor Penerimaan Orang Tua

\begin{tabular}{lccc}
\hline Kategori & Skor & Jumlah & Persentase \\
\hline Rendah & $<124$ & 30 & 48 \\
Sedang & $124-133$ & 16 & 26 \\
Tinggi & $>133$ & 16 & 26 \\
\hline Total & & 62 & 100 \\
\hline
\end{tabular}

Berdasarkan tabel 5, terlihat bahwa mayoritas responden penelitian memiliki tingkat penerimaan yang rendah terhadap kondisi anaknya (48 \%). Dengan kata lain, mereka masih belum dapat menerima kondisi retardasi mental yang dimiliki oleh anak mereka.

\section{F. PEMBAHASAN}

Perhitungan kategori penerimaan responden penelitian yang merupakan orang tua dari anak retardasi mental menggunakan norma kelompok dengan teknik persentil. Hasil perhitungan norma menunjukkan bahwa mayoritas responden penelitian memiliki tingkat penerimaan yang rendah, atau dengan pengertian lain mereka belum dapat menerima kondisi retardasi mental pada anak mereka (48\%). Menurut Hendirati, Handariyati, dan Sakti (2006), faktor-faktor yang mempengaruhi sikap penerimaan rendah seperti hubungan keluarga yang kurang komunikatif, tidak adanya pemahaman tentang retardasi mental, ketidaksiapan menghadapi kondisi anak, dan persepsi yang cenderung negatif terhadap 
anak. Pendapat tersebut didukung dengan hasil open-ended yang diberikan peneliti terhadap responden penelitian, yang menunjukkan bahwa orang tua cenderung melihat anak retardasi mental adalah anak yang penuh dengan keterbatasan, seperti kurang mampu berkomunikasi, memiliki perilaku yang tidak menyenangkan (seperti, buang air di celana, emosi yang meledak-ledak). Dalam open-ended, juga disebutkan bahwa orang tua masih melihat adanya reaksi negatif dari masyarakat terhadap anak dengan retardasi mental di mana hal ini dapat mempengaruhi penerimaan orang tua terhadap keterbatasan anak mereka.

Hasil penelitian juga menunjukkan bahwa terdapat 26 persen orang tua yang memiliki tingkat penerimaan sedang dan tinggi, atau dalam pengertian lain orang tua cukup dapat menerima kondisi anak dengan retardasi mental. Faktor-faktor yang dapat mempengaruhi penerimaan orang tua pada anak retardasi mental adalah memberikan perasaan positif pada anak, mendengarkan anak dengan pikiran yang terbuka, latar belakang agama yang kuat, dan dukungan dari lingkungan (Moningsih, 2012). Hal ini didukung dengan hasil openended yang menyatakan bahwa sebagian besar orang tua masih memiliki harapan terhadap anak mereka, seperti bisa hidup mandiri, dapat diterima dan berguna di masyarakat, tumbuh seperti layaknya anak normal, menunjukkan kemajuan yang berarti. Sikap menerima tidak lepas dari keyakinan orang tua terhadap Tuhan. Hasil open ended pada butir pertanyaan alasan orang tua dapat menerima kondisi anak mereka, sebagian besar menjawab karena mereka merasa anak adalah titipan dan anugerah dari Tuhan. Latar belakang agama yang kuat yang banyak mendorong orang tua untuk memiliki kesabaran dalam mengasuh dan membesarkan anak mereka.

\section{G. SIMPULAN}

Berdasarkan hasil penelitian, dapat disimpulkan bahwa penerimaan orang tua terhadap kondisi anak mereka yang memiliki retardasi mental cenderung rendah.

\section{H. SARAN}

Saran teoritis dalam penelitian ini adalah sebaiknya dilakukan expert judgement terhadap instrumen penelitian yang disusun sendiri oleh peneliti, agar bisa mengetahui dengan jelas content validity dari instrumen tersebut. Untuk penelitian selanjutnya, penyusunan instrumen bisa didasarkan dengan teori penerimaan dari tokoh/pakar yang lain 
Vol. 9 No. 1 April 2016

PSIBERNETIKA

sehingga bisa mendapatkan gambaran yang lebih komprehensif. Penelitian selanjutnya juga dapat mengaitkan dengan variabel lainnya, seperti kecerdasan emosional anak, prestasi akademik, dan sebagainya.

Bagi orang tua, disarankan untuk dapat lebih terlibat aktif dalam aktivitas-aktivitas yang dilakukan oleh anak. Keterlibatan orang tua secara langsung dapat membantu orang tua untuk lebih menerima kondisi anak. Orang tua juga dapat menciptakan hubungan yang lebih komunikatif dengan anak dan tidak hanya fokus pada keterbatasan anak, melainkan melakukan usaha-usaha untuk mengembangkan potensi anak, misalnya dengan mengikutsertakan anak pada kegiatan melukis, menari, atau kegiatan lain yang sesuai dengan hobi dan potensi anak.

Bagi sekolah, disarankan mengadakan parenting education berupa seminar yang rutin mengenai pentingnya sikap penerimaan orang tua. Sekolah juga dapat mengadakan kegiatan yang melibatkan langsung antara orang tua dengan siswa/i sehingga orang tua dapat lebih meluangkan waktu dengan anak mereka, misalnya karyawisata, makan bersama, dan lain sebagainya.

\section{DAFTAR PUSTAKA}

Benny,F., Nurdin,A.E., \& Chundrayetti,E. (2014). Penerimaan Ibu yang Memiliki Anak Retardasi Mental. Jurnal Kesehatan Andalas. 3(2).

Elianto, H., \& Hendriani, W. (2013). Hubungan Kecerdasan Emosi dengan Penerimaan Ibu terhadap Anak Kandung yang Mengalami Celebral Palsy. Jurnal Psikologi Pendidikan Dan Perkembangan. Vol 2 (2). Diakses dari http://journal.unair.ac.id/filerPDF/jpppb14962ae24full.pdf pada 09 April 2015.

Farraswati, D.I., \& Siswanto, H. (2014). Pola Asuh Keluarga pada Penyandang Tunagrahita di Desa Karangpatihan Kecamatan Balong Kabupaten Ponorogo. Jurnal Elektoronik UNESA. Diakses dari ejournal.unesa.ac.id/article/17091/14/article.pdf pada 09 April 2015

Garguilo, R.M. (1985). Working with Parents of Exceptional Children : a guide for professional. Boston : Houghton Mifflin Company.

Gravetter,F.J., \& Forzano.L.B. (2012). Research Methods for The Behavioural Sciences. Canada: Wadsworth Cengage Learning.

Hendriani, W., Handariyati, R., dan Sakti,T.M. (2006). Penerimaan Keluarga terhadap Individu yang Mengalami Keterbelakangan Mental. Jurnal Insan Vol. 8 ( 2 ). 
Ilmi,B., Wahyuni, S., Mato. R. (2012). Hubungan Pola Asuh Orang Tua terhadap Perkembangan Sosial Anak Retardasi Mental di SLB C YPPLB Cendrawasih Makassar. Jurnal ISSN vol.1(5). Diakses dari library.stikesnh.ac.id./e-library\%20stikes\%20nani\%2 pada 18 Maret 2015.

Kumar,R. (2014). Research Methodology : a step by step guide for beginners. Fourth Edition. India: Sage.

Magunsong,F (2009). Psikologi dan Pendidikan Anak Berkebutuhan Khusus : Jilid Kesatu. Depok : Lembaga Pengembangan Sarana Pengukuran Dan Pendidikan Psikologi (LPSP3).

Moningsih, I. (2012). Penerimaan Orang Tua pada Anak Mental Retardation. Diakses dari publication.gunadarma.ac.id/handle/123456789/3521 pada 18 Maret 2015.

Nisfiannoor,M (2009). Pendekatan Statiska Modern untuk Ilmu Sosial. Jakarta: Salemba Humanika.

Payne, J.S., \& Patton,J.R. (1981). Mental Retardation. Ohio : A Bell \& Howell Company.

Permana,R.H., Ekowati,W., \& Nani,D. (2013). Pengaruh Dukungan Sosial terhadap Kemampuan Sosialisasi Anak Berkebutuhan Khusus. Diakses dari download.portalgaruda.org/article.php?article.val pada 18 Maret 2015.

Prasa, B. A. (2012). Stres dan Koping Orang Tua dengan Anak Retardasi Mental. Jurnal. Universitas Ahmad Dahlan: Yogyakarta. Diakses dari http://download.portalgaruda.org/article.php?article $=123299 \& v a l=5545$ pada 09 April 2015

Rohner, R. P., \& Khaleque, A. (2002). Parental Acceptance-Rejection and Life-Span Development: A Universalist Perspective. Jurnal Online Reading In Psychology And Culture. Diakses dari http://scholarworks.gvsu.edu/cgi/viewcontent.cgi?art pada 09 April 2015

Sarasvati (2004). Meniti Pelangi : Perjuangan Seorang Ibu yang Tidak Kenal Menyerah dalam Membimbing Putranya Keluar dari Belenggu Adhd dan Autisme. Jakarta : Elex Media Computindo.

Sholihah, Asiyah,N., \& Masithoh,A.R. (2014). Pengaruh Terapi-Terapi Kelompok Suportif terhadap Beban Keluarga dalam Merawat Anak Tunagrahita di Sekolah Luar Biasa Kaliwungu dan Purwosari Kabupaten Kudus. Jurnal JIKK Vol 5(1). 1-13. Diakses dari ejournal.stikesmuhkudus.ac.id/index.php/148/95 pada 09 April 2015

Slameto (2013). Belajar dan Faktor-Faktor yang Mempengaruhi. Jakarta : Rineka Cipta.

Taylor,R.L., Richards,S.B., \& Brady,M.P. (2005). Mental Retardation : Historical Perspective, Current Practices, and Future Direction. USA : Pearson Education. Inc. 